\title{
Diagnostic value of soluble CD14 subtype (sCD14-ST) presepsin for the postmortem diagnosis of sepsis-related fatalities
}

\author{
Cristian Palmiere • Michele Mussap • Daniel Bardy • \\ Francesco Cibecchini $\cdot$ Patrice Mangin
}

Received: 25 September 2012 / Accepted: 30 November 2012 / Published online: 22 December 2012

(C) Springer-Verlag Berlin Heidelberg 2012

\begin{abstract}
The first aim of this study was to assess the diagnostic performance of presepsin (sCD14-ST) in postmortem serum from femoral blood compared to procalcitonin (PCT) to detect sepsis-related fatalities. The second aim was to compare sCD14-ST levels found in postmortem serum to the values in pericardial fluid to investigate the usefulness of the latter as an alternative biological fluid. Two study groups were formed, a sepsis-related fatalities group and a control group. Radiology (unenhanced CT scans and postmortem angiographies), autopsies, histology, neuropathology, and toxicology as well as other postmortem biochemistry investigations were performed in all cases. Microbiological investigations on right cardiac blood were carried out exclusively in septic cases. The results of this study indicated that postmortem serum PCT and SCD14-ST levels, individually considered, allowed septic cases to be identified. Even though increases in both PCT and SCD14ST concentrations were observed in the control cases, coherent PCT and SCD14-ST results in cases with suspected sepsis allowed the diagnosis to be confirmed. Conversely, no relevant correlation was identified between postmortem serum and pericardial fluid SCD14-ST levels in either the septic or control groups.
\end{abstract}

C. Palmiere $(\bowtie) \cdot$ P. Mangin

University Centre of Legal Medicine, Rue du Bugnon 21,

1011 Lausanne, Switzerland

e-mail: cristian.palmiere@chuv.ch

M. Mussap $\cdot$ F. Cibecchini

Department of Laboratory Medicine,

University Hospital San Martino, Largo R. Benzi 10,

16132 Genova, Italy

D. Bardy

Laboratory of Clinical Chemistry, Lausanne University Hospital, 1011 Lausanne, Switzerland
Keywords Presepsin · Soluble CD14 subtype · Sepsis · Procalcitonin $\cdot$ Postmortem biochemistry

\section{Introduction}

Sepsis remains a major challenge in clinical practice with considerable morbidity and mortality despite modern treatments. Clinicians are in need of good diagnostic and prognostic markers in order to identify infected patients who would rapidly benefit from prompt, empirical antibiotic therapy and other supportive treatment. Increased knowledge on the pathophysiology and immunopathogenesis of sepsis could therefore have the potential of generating new diagnostic options and treatment modalities for this serious condition [1].

In the realm of forensic pathology, notwithstanding extensive research and development in immunohistochemistry and postmortem biochemical investigations, reliable diagnoses of sepsis still remain difficult to formulate due to a variety of reasons: unavailability of medical records before autopsy is performed, uncertainty of macroscopic and microscopic findings as well as imprecise postmortem culture results since accuracy may be influenced by postmortem bacterial contamination [2].

In clinical practice, much effort has been directed towards identifying biochemical parameters whose determination may provide useful information in the detection of inflammatory states and confirm the existence of bacterial infections. In general, C-reactive protein (CRP) is considered the biomarker of choice in detecting inflammations, regardless of whether they are triggered by bacterial infections. Other biomarkers, such as procalcitonin (PCT) and lipopolysaccharide-binding protein (LBP), seem to have a pivotal role in the inflammatory host response to microbial infections and are currently used in clinical practice as 
biological parameters to diagnose sepsis or severe bacterial sepsis $[3,4]$.

In the forensic field, CRP and PCT can easily be measured in biological fluids obtained during autopsy (mainly peripheral blood, cardiac blood, and postmortem serum) and may be similarly used as in clinical practice $[5,6]$. However, their diagnostic performance in identifying sepsis-related outcomes is incomplete. Despite its undoubted helpfulness in identifying inflammatory states, increased CRP levels can be observed in several non-infectious conditions [7-10]. Likewise, a number of non-infectious causes may induce increased PCT levels including major surgery, severe trauma without bacterial infections, exertion heat stroke, and major burns [11-16].

Due to the complexity of the sepsis response, some authors have postulated that a combination of several biological markers, rather than a single laboratory parameter, could be more effective in order to obtain early and reliable diagnosis of sepsis in living patients [17]. This same consideration may be applied to the forensic field, where the diagnosis of sepsis is even more difficult.

$\mathrm{CD} 14$, a cluster of differentiation (CD) marker protein expressed on the surface of various cells including monocytes, macrophages, neutrophils, and B cells is a multifunctional cell surface glycoprotein, which exists either in a glycosylphosphatidylinositol (GPI)-anchored membrane form (mCD14) or in a circulating soluble form (sCD14) [17-19]. Circulating plasma proteases activate a cleavage of sCD14, generating a $13-\mathrm{kDa}$ truncated N-terminal fragment of 64 amino acid residues named sCD14 subtype (sCD14-ST) or presepsin [17]. Yaegashi et al. [19] observed that the concentration of SCD14-ST was increased in patients with sepsis compared to healthy individuals and patients with systemic inflammatory response syndrome (SIRS). Analogous results were obtained by Endo et al. [4] in a multicenter prospective study where sCD14-ST levels in patients with systemic and localized bacterial infections were significantly higher than those in patients with nonbacterial infectious diseases.

In the study herein described, sCD14-ST, PCT, and CRP levels were measured in postmortem serum from femoral blood and pericardial fluid in a series of sepsis-related fatalities and control individuals who underwent medicolegal investigations. The first objective of this study was to assess the diagnostic performance of sCD14-ST compared to PCT to detect sepsis-related fatalities. The second aim was to compare postmortem serum SCD14-ST levels to pericardial fluid concentrations to test the practicability of using pericardial fluid as an alternative biological fluid. Unenhanced CT scans, autopsy, histology, neuropathology, and toxicology as well as other postmortem biochemical analyses were also performed in all cases selected for this study.

\section{Material and methods}

Subjects

Two study groups were formed, a sepsis-related fatalities group and a control group. The sepsis-related fatalities group consisted of 19 forensic autopsy cases. Nine of these had been admitted to the intensive care unit of local hospitals, where they died, and had documented clinical diagnoses of sepsis in vivo. The period of the septic condition was between $24 \mathrm{~h}$ and 4 days.

No documented diagnoses of sepsis in vivo were noted in the other ten cases, with no admittance to hospital prior to death. Medical records were consistent with the existence of infectious diseases. However, due to unclear circumstances of death, autopsies were ordered by the public prosecutor and the bodies transferred to the medicolegal center.

All cases included in the septic group $(n=19)$ underwent complete autopsies between 5 and 62 hours after death (mean postmortem period $19 \mathrm{~h}$ ). The autopsies were always preceded by unenhanced CT scans and, in selected cases, postmortem angiographies. Histology, neuropathology, toxicology, and microbiological investigations on right cardiac blood were performed in all cases of this group as well as biochemical analyses on postmortem serum from femoral blood and vitreous humor.

The hypothesis of sepsis and multiple organ failure as the cause of death was confirmed by postmortem investigations in all the nine cases that had clinical diagnoses in vivo, along with the exclusion of other causes of death.

The cause of death was attributed to multiple organ failure in all ten cases that did not have clinical diagnoses of sepsis in vivo based on the results of postmortem investigations. Underlying septic states were postulated as the cause of multiple organ failure. Alternative causes of death were excluded based on autopsy and other forensic analyses. Descriptive characteristics of the studied subjects, laboratory results, and main postmortem investigation findings are reported in Table 1.

The control group consisted of 18 forensic autopsy cases. None of the subjects included in this group had a documented, clinical diagnosis of sepsis in vivo and none had been admitted to the hospital prior to death. As with the group above, complete forensic autopsies were performed between 8 and $65 \mathrm{~h}$ after death (mean $30 \mathrm{~h}$ ), always preceded by unenhanced CT scans and, in selected cases, by postmortem angiographies. Histology, neuropathology, and toxicology were performed in all cases, as well as biochemical analyses on postmortem serum from femoral blood and vitreous humor. Microbiology was not performed in any of the cases of this group. Postmortem investigations failed to reveal findings consistent with the existence of underlying bacterial infections or septic states.

Causes of death were determined to be drug intoxication (four cases), hanging (two cases), coronary thrombosis 
Table 1 Results for the septic group ( $n=19,11$ males and 8 females, mean age 49.5 years) with characteristics of the investigated subjects, laboratory results (postmortem serum), and main postmortem investigation findings

\begin{tabular}{|c|c|c|c|c|c|c|c|c|c|}
\hline Subject & $\begin{array}{l}\text { Postmortem } \\
\text { interval (h) }\end{array}$ & Age & Gender & $\begin{array}{l}\text { Clinical } \\
\text { diagnosis } \\
\text { of sepsis }\end{array}$ & PCT & CRP & sCD14-ST & $\begin{array}{l}\text { Microbiology } \\
\text { findings }\end{array}$ & $\begin{array}{l}\text { Medical records, } \\
\text { radiology, autopsy, } \\
\text { and histology findings }\end{array}$ \\
\hline 1 & 23 & 63 & M & Yes & 20.28 & 172 & 5,280 & m.b. & Pneumoniae \\
\hline 2 & 25 & 46 & $\mathrm{~F}$ & Not & 23.37 & 270 & 4,910 & m.b. & Peritonitis \\
\hline 3 & 34 & 70 & $\mathrm{M}$ & Not & 2.62 & 62 & 8,960 & P. aeruginosa & $\begin{array}{l}\text { Necrotising myocarditis, } \\
\text { fibrinous pericarditis, } \\
\text { pneumonia }\end{array}$ \\
\hline 4 & 15 & 48 & $\mathrm{~F}$ & Not & 13.50 & 372 & 1,890 & E. coli & Pyelonephritis \\
\hline 5 & 14 & 49 & $\mathrm{M}$ & Not & 0.06 & 76 & 2,280 & m.b. & $\begin{array}{l}\text { Pneumonia, antibiotic } \\
\text { treatment }\end{array}$ \\
\hline 6 & 14 & 80 & $\mathrm{~F}$ & Not & 2.76 & 61 & 750 & E. coli & Pneumonia \\
\hline 7 & 5 & 57 & $\mathrm{~F}$ & Not & 155.70 & 229 & 4,420 & m.b. & Abdominal infection \\
\hline 8 & 62 & 63 & $\mathrm{~F}$ & Not & 13.62 & 306 & 2,810 & m.b. & Peritonitis \\
\hline 9 & 21 & 74 & $\mathrm{~F}$ & Not & 2.31 & 98 & 1,170 & m.b. & $\begin{array}{l}\text { Alzheimer, broncho-aspiration } \\
\text { pneumonia }\end{array}$ \\
\hline 10 & 5 & $\begin{array}{l}2 \text { months } \\
\text { old }\end{array}$ & $\mathrm{M}$ & Yes & 47.13 & 3 & 92 & K. pneumoniae & $\begin{array}{l}\text { Pneumonia, percutaneous } \\
\text { gastrostomy tube }\end{array}$ \\
\hline 11 & 22 & 46 & M & Yes & 3.77 & 58 & 1,750 & E. coli & Pneumonia \\
\hline 12 & 12 & 17 & M & Yes & 16.58 & 25 & 1,760 & K. pneumoniae & $\begin{array}{l}\text { Sickle cell disease, } \\
\text { lymphadenomegaly, } \\
\text { splenomegaly, pneumonia }\end{array}$ \\
\hline 13 & 10 & 66 & M & Yes & 85.50 & 285 & 2,220 & P. aeruginosa & Pneumonia \\
\hline 14 & 11 & 32 & M & Yes & 6.04 & 56 & 1,680 & n.i. & Multiple organ failure \\
\hline 15 & 15 & 78 & M & Yes & 8.87 & 130 & 1,680 & E. coli & Pneumonia \\
\hline 16 & 18 & 48 & $\mathrm{~F}$ & Yes & 27.75 & 150 & 4,160 & K. pneumoniae & Pneumonia \\
\hline 17 & 23 & 41 & $\mathrm{~F}$ & Yes & 4.02 & 161 & 1,470 & m.b. & Pneumonia, antibiotic therapy \\
\hline 18 & 12 & 17 & M & Not & 3.68 & 148 & 1,770 & E. coli & Pneumonia \\
\hline 19 & 27 & 45 & M & Not & 47.34 & 272 & 1,310 & E. coli & Necrotising fasciitis \\
\hline
\end{tabular}

$M$ male; $F$ female; $P C T$ procalcitonin (results are expressed in micrograms per milliliter); CRP C-reactive protein (results are expressed in milligrams per liter); $s C D 14-S T$ soluble cluster of differentiation 14 subtype (results are expressed in picograms per milliliter); n.i. not clearly identifiable pathogens; $m . b$. multiple bacteria

(three cases), ischemic heart disease (two cases), chronic myocardial insufficiency (one case), carbon monoxide intoxication (one case), positional asphyxia (one case), and hepatic insufficiency (one case). In one case, death occurred in the context of generalized seizures. In two cases, the causes of death remained undetermined even after all postmortem investigations had been performed. Both cases occurred in women presenting chronic eating disorders. Descriptive characteristics of the control group subjects, laboratory results, main postmortem investigation findings and causes of death are reported in Table 2.

Sample collection

\section{Postmortem serum from femoral blood}

Using a sterile needle and syringe, postmortem blood samples were collected by aspiration through the femoral vein during autopsy. All blood samples were centrifuged immediately post-collection at $3,000 \times \mathrm{g}$ for $15 \mathrm{~min}$. After centrifugation, the separated supernatant (postmortem serum) was collected, stored in preservative-free tubes, and frozen at $-20{ }^{\circ} \mathrm{C}$ until analysis.

\section{Right cardiac blood}

The external side of the right atrium was sterilized by searing with a heated scalpel blade, and the cardiac blood was aspirated using a syringe. Once collected, the blood was stored in blood-culture bottles (aerobic and anaerobic) and immediately incubated at $37^{\circ} \mathrm{C}$.

\section{Pericardial fluid}

Undiluted samples of pericardial fluid were collected immediately post pericardium incision during autopsy. 
Table 2 Results for the control group $(n=18,11$ males and 7 females, mean age 45 years) with characteristics of the investigated subjects, laboratory results (postmortem serum), main postmortem investigation findings, and causes of death

$M$ male; $F$ female; $P C T$ procalcitonin (results are expressed in micrograms per milliliter); $C R P$ $\mathrm{C}$-reactive protein (results are expressed in milligrams per liter); $s C D 14-S T$ soluble cluster of differentiation 14 subtype (results are expressed in picograms per milliliter)

\begin{tabular}{llllllll}
\hline Subject & $\begin{array}{l}\text { Postmortem } \\
\text { interval (h) }\end{array}$ & Gender & Age & PCT & CRP & $\begin{array}{l}\text { sCD14- } \\
\text { ST }\end{array}$ & $\begin{array}{l}\text { Radiology, autopsy, histology, } \\
\text { and toxicology findings }\end{array}$ \\
\hline 20 & 65 & M & 35 & 0.06 & 2 & 210 & Coronary thrombosis \\
21 & 42 & M & 22 & 0.06 & 2 & 480 & Toxic (heroin) \\
22 & 48 & F & 66 & 0.35 & 17 & 4,890 & Hepatic insufficiency \\
23 & 12 & M & 57 & 0.06 & 2 & 890 & Toxic (multiple drugs) \\
24 & 42 & F & 45 & 0.06 & 2 & 650 & Coronary thrombosis \\
25 & 15 & F & 44 & 0.06 & 2 & 290 & Hanging \\
26 & 24 & M & 45 & 0.06 & 2 & 510 & Coronary thrombosis \\
27 & 33 & F & 46 & 0.06 & 2 & 410 & Toxic (carbon monoxide) \\
28 & 18 & F & 58 & 0.06 & 2 & 180 & Toxic (multiple drugs) \\
29 & 8 & M & 43 & 0.06 & 2 & 830 & Chronic myocardial insufficiency \\
30 & 20 & M & 70 & 0.06 & 2 & 690 & Ischemic heart disease \\
31 & 23 & M & 55 & 0.06 & 2 & 270 & Ischemic heart disease \\
32 & 9 & M & 27 & 0.06 & 2 & 380 & Hanging \\
33 & 18 & F & 33 & 0.06 & 2 & 1,460 & Undetermined (eating disorder) \\
34 & 32 & M & 42 & 0.06 & 2 & 1,170 & Epilepsy \\
35 & 51 & M & 46 & 5.21 & 52 & 1,170 & Toxic (multiple drugs) \\
36 & 24 & M & 61 & 8.26 & 11 & 1,570 & Positional asphyxia \\
37 & 48 & F & 31 & 25.48 & 85 & 1,840 & Undetermined (eating disorder, \\
& & & & & & & renal insufficiency) \\
\hline
\end{tabular}

All samples were immediately centrifuged at $3000 \times g$ for $15 \mathrm{~min}$. After centrifugation, the separated supernatant was collected, stored in preservative-free tubes and frozen at $-20{ }^{\circ} \mathrm{C}$ until analysis.

\section{Laboratory assays}

\section{Determination of PCT concentrations}

PCT was measured by commercially available immunoassays on the Roche Modular E170 analyzer (Roche Diagnostic, Mannheim, Germany) using a postmortem serum from femoral blood. Results were expressed in micrograms per liter. The analytical sensitivity was $0.1 \mu \mathrm{g} / \mathrm{l}$, according to manufacturer information.

\section{Determination of CRP concentrations}

CRP was measured by the commercially available immunoturbidometric assay on the Roche Modular Psystem (Roche Diagnostics, Mannheim, Germany) using postmortem serum from femoral blood. Results were expressed in milligrams per liter. The analytical sensitivity was $0.15 \mathrm{mg} / \mathrm{l}$, according to manufacturer information.

\section{Determination of SCD14-ST concentrations}

sCD14-ST concentrations were measured by a rapid, commercially available chemiluminescent enzyme immunoassay (CLEIA) based on a noncompetitive CLEIA combined with Magtration ${ }^{\circledR}$ technology [20]. The method was optimized on an automated immunoassay analyzer (PATHFAST ${ }^{\mathrm{TM}}$, Gepa Diagnostics, Milan, Italy) [21]. During incubation of the sample with alkaline phosphatase-labeled anti sCD14-ST polyclonal and monoclonal antibodies coated with magnetic particles, sample sCD14-ST presepsin binds to the antibodies forming an immunocomplex with enzyme-labeled antibodies and antibody-coated magnetic particles. After removing the unbound substances via Magtration ${ }^{\circledR}$ technology, a chemiluminescent substrate is added. After a short incubation, the luminescence intensity generated by the enzyme reaction, which is proportional to the SCD14-ST concentration, is measured. The final result is calculated by means of a standard calibration curve performed by using a standard calibrator material containing recombinant $\mathrm{SCD} 14-\mathrm{ST}$; the calibrator value was assigned by amino acid analysis. Results are automatically corrected by entering the corresponding hematocrit value. Quality specifications of this CLEIA have been previously assessed, according to CLSI EP17-A [21, 22]. Intra-assay imprecision, expressed as coefficient of variation (in percentage) ranges from 2.7 to $7.1 \%$ with linearity of $94.7-104.6 \%$ 
In our study, postmortem serum from femoral blood and pericardial fluid were used as samples. Results were expressed in picograms per milliliter. The analytical sensitivity was $20 \mathrm{pg} / \mathrm{ml}$, according to manufacturer information.

Other analyses

Other biochemical analyses were performed according to laboratory standards and internal quality control protocols.

\section{Ethical aspect}

All cases collected for this study underwent medicolegal autopsies as requested by the public prosecutor. Biochemical analyses, including PCT, CRP, and sCD14-ST measurements, were performed as part of the medicolegal investigations. No further ethical permission was required to perform laboratory analyses.

\section{Statistical analyses}

Data were analyzed by using STATA statistical software package (STATA Corporation, College Station, TX, USA). Receiver-operator characteristic curves, sensitivity, and specificity values were calculated to assess the performance of the selected biomarkers as diagnostic markers for sepsis. The diagnostic accuracy of the studied markers was determined by the area under the curves (AUC). According to laboratory references in living people, PCT values were dichotomized into "non-septic values" (concentrations lower than $2 \mu \mathrm{g} / \mathrm{l}$ ) and "septic values" (concentrations greater than $2 \mu \mathrm{g} / \mathrm{l}$ ), and CRP values into "normal values" (concentrations lower than $10 \mathrm{mg}$ / 1) and "increased values" (concentrations greater than $10 \mathrm{mg} / \mathrm{l}$ ). A cutoff value of $600 \mathrm{pg} / \mathrm{ml}$ was chosen for sCD14-ST based on the results of the clinical study of Endo et al. [4]. According to these authors, this value yielded optimal sensitivity and specificity for the diagnosis of bacterial infections in living people. The relationship between sCD14-ST in postmortem serum and sCD14-ST in pericardial fluid was explored: the non-parametric measure of dependence between the two variables was expressed as Spearman's rank correlation coefficient or Spearman's rho. The linear dependence between the two variables was assessed by Pearson's product-moment coefficient. $R$ and Rho values $\geq 0.7$ were considered to define a strong correlation between variables, respectively; while $\mathrm{R}$ and Rho ranging between 0.69 and 0.5 and 0.49 to 0.3 were considered to define moderate and low correlation, respectively.

\section{Results}

Tables 1 and 2 summarize the main laboratory results (postmortem serum PCT, CRP, and sCD14-ST levels) and autopsy findings in the sepsis cases and control individuals. The bivariate fit of postmortem serum and pericardial fluid sCD14-ST concentrations in the sepsis (Fig. 1a) and control group (Fig. 1b) is reported in Fig. 1. Statistical results are reported in Table 3.

Sepsis and multiple organ failure were confirmed to be the causes of death according to postmortem investigations in all the nine cases that had clinical diagnoses of sepsis in vivo and the exclusion of other causes of death.

The cause of death was attributed to multiple organ failure in the other ten cases that did not have clinical diagnoses of sepsis in vivo based on the results of postmortem investigations. Underlying septic states were postulated as provoking multiple organ failures. Alternative causes of death were excluded according to autopsy and further postmortem investigations.

Assuming that normal and pathological PCT and CRP blood levels in living people show similar ranges as in postmortem serum from femoral blood, only one individual (case 5) among the sepsis-related fatalities presented a normal postmortem serum PCT value $(0.06 \mu \mathrm{g} / \mathrm{l})$, though with an increased postmortem serum CRP concentration ( $76 \mathrm{mg} /$ 1). The sCD14-ST value was also increased $(2,280 \mathrm{pg} / \mathrm{ml})$ in this case. Blood cultures revealed the presence of multiple Gram-positive and Gram-negative bacteria. Histology revealed multiple foci of polynuclear neutrophils in both lungs.

Furthermore, only one individual (case 10) among the sepsis-related fatalities presented a normal postmortem serum CRP value $(3 \mathrm{mg} / \mathrm{l})$, whereas postmortem serum PCT concentration was significantly increased $(47.13 \mathrm{mg} / \mathrm{l})$. Interestingly, the sCD14-ST value $(92 \mathrm{pg} / \mathrm{ml})$ was the lowest observed in either study group. This case, a 2-month-old infant, represented the only CRP and sCD14-ST negative case in the sepsis group.

Among septic cases, sCD14-ST concentrations ranged from 92 to $8,960 \mathrm{pg} / \mathrm{ml}$, with a mean value of $2,650 \mathrm{pg} /$ $\mathrm{mg}$ (median 4,420 pg/ml). In 18 cases out of 19 , sCD14-ST levels were higher than $600 \mathrm{pg} / \mathrm{ml}$ (cutoff value).

Increased levels of both PCT and SCD14-ST were observed in 17 septic cases out of 19, of both PCT and CRP in 17 cases out of 19, and of both CRP and SCD14-ST in 18 cases out of 19. Lastly, increased PCT, CRP, and SCD14-ST concentrations were simultaneously observed in 17 cases out of 19 .

In the 18 control individuals, postmortem investigations failed to identify findings consistent with the existence of underlying bacterial infections or septic states.

Again, assuming that normal and pathological PCT and CRP blood levels in living people show similar ranges in postmortem serum from femoral blood, three cases were observed that revealed simultaneous increases in both PCT and sCD14-ST levels (cases 35, 36, and 37). These cases also showed higher CRP levels. PCT concentrations were 
Fig. 1 Bivariate fit of postmortem serum and pericardial fluid sCD14-ST concentrations in the sepsis cases (a) and control individuals (b)
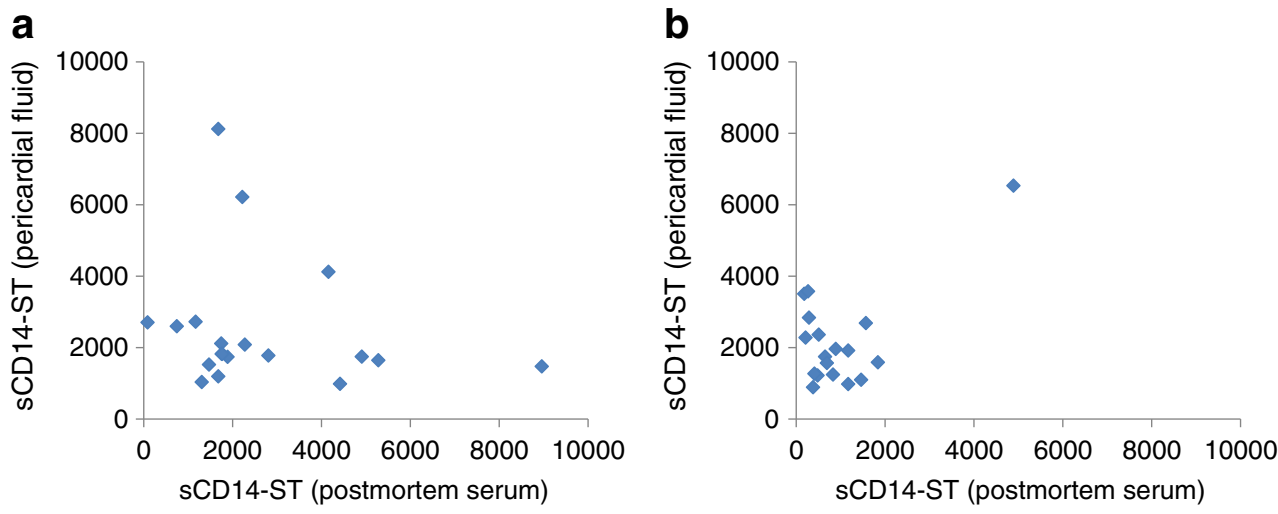

lower than $2 \mu \mathrm{g} / \mathrm{ml}$ in 15 cases out of 18, and CRP levels were normal in 14 out of 18 .

sCD14-ST values ranged from 180 to $4,890 \mathrm{pg} / \mathrm{ml}$, with a mean value of $993 \mathrm{pg} / \mathrm{mg}$ (median $670 \mathrm{pg} / \mathrm{ml}$ ). Concentrations were greater than $600 \mathrm{pg} / \mathrm{ml}$ in ten cases out of 18 . Among them, sCD14-ST was the only increased parameter in six cases (cases 23, 24, 29, 30, 33, 34).

As expected, postmortem serum PCT values were higher in the sepsis group and differed between the two groups, with only one false-negative case in the sepsis group (which showed both increased CRP and sCD14-ST levels) and three false-positives in the control group (which also showed both increased CRP and sCD14-ST levels).

Similarly, postmortem serum CRP levels were higher in the sepsis group and differed between the two groups, with only one false-negative case in the sepsis group (which also showed a normal sCD14 level) and four false-positives in the control group (among these, three cases also showed both increased PCT and SCD14-ST levels and one case showed a significantly increased SCD14-ST value).

Using a cutoff value of $600 \mathrm{pg} / \mathrm{ml}, \mathrm{sCD} 14-\mathrm{ST}$ determination in postmortem serum revealed one falsenegative case in the sepsis group and ten falsepositives in the control group (sensitivity $94.74 \%$, specificity $44.44 \%$ ). PCT in postmortem serum showed the same sensitivity as sCD14-ST (94.74\%), whereas specificity $(83.33 \%)$ was better.

Using a cutoff value of $750 \mathrm{pg} / \mathrm{mg}$, sensitivity and specificity were unchanged; whereas using a cutoff value of $1,200 \mathrm{pg} / \mathrm{ml}, \mathrm{sCD} 14-\mathrm{ST}$ determination revealed three falsenegative cases in the sepsis group and four false-positives in the control group, with a sensitivity of $84.21 \%$ and a specificity of $77.78 \%$ (AUC 0.81).

The simultaneous determination of both PCT and SCD14ST (cutoff $600 \mathrm{pg} / \mathrm{ml}$ ) showed satisfactory sensitivity and specificity ( 89.47 and $83.33 \%$, respectively, AUC 0.91). Using a cutoff value of $1,200 \mathrm{pg} / \mathrm{ml}$, the sensitivity was $100 \%$ and specificity, $72.22 \%$ (AUC 0.92).

Lastly, the results of the data analysis showed that pericardial fluid sCD14-ST levels were similar in both studied groups, thereby suggesting that pericardial fluid SCD14-ST determination cannot be considered an option should postmortem serum be unavailable.

Figure 1 shows the bivariate fit of postmortem serum and pericardial fluid sCD14-ST concentrations in the sepsis cases (Fig. 1a) and control individuals (Fig. 1b). No monotonic correlation exists between the two variables (Spearman's rho $=-0.28$ and -0.14 in the sepsis and control groups, respectively, and $p$ value $>0.2$ for both groups) and no linear dependence between the two variables was

Table 3 Sensitivity, specificity, and area under the curve for PCT, CRP, and SCD14-ST in postmortem serum and pericardial fluid

\begin{tabular}{llllllll}
\hline & PCT S & CRP S & $\begin{array}{l}\text { sCD14-ST S } \\
\text { (cutoff value } 600 \\
\text { pg/ml) }\end{array}$ & sCD14-ST PF & $\begin{array}{l}\text { PCT and sCD14-ST } \\
\text { (cutoff value 600 pg/ml) }\end{array}$ & $\begin{array}{l}\text { sCD14-ST S } \\
\text { (cutoff value } \\
1,200 \mathrm{pg} / \mathrm{ml} \text { ) }\end{array}$ & $\begin{array}{l}\text { PCT and sCD14-ST } \\
\text { (cutoff value 1,200 } \\
\mathrm{pg} / \mathrm{ml} \text { ) }\end{array}$ \\
\hline Sensitivity & $94.74 \%$ & $94.74 \%$ & $94.74 \%$ & $94.74 \%$ & $89.47 \%$ & $84.21 \%$ & $100 \%$ \\
Specificity & $83.33 \%$ & $77.78 \%$ & $44.44 \%$ & 0 & $83.33 \%$ & $77.78 \%$ & $72.22 \%$ \\
AUC & 0.89 & 0.96 & 0.84 & 0.54 & 0.91 & 0.81 & 0.92 \\
False positive & 3 & 4 & 10 & 18 & 3 & 4 & 5 \\
False negative & 1 & 1 & 1 & 0 & 2 & 3 & 0 \\
\hline
\end{tabular}

$S$ postmortem serum from femoral blood; $P F$ pericardial fluid; $P C T$ procalcitonin (results are expressed in micrograms per milliliter); $C R P C$ reactive protein (results are expressed in milligrams per liter); $s C D 14-S T$ soluble cluster of differentiation 14 subtype (results are expressed in picograms per milliliter); $A U C$ area under the curve 
shown by Pearson's product-moment coefficient in the sepsis group ( $r$ squared $=0.03$, correlation $=-0.179, p$ value 0.46). Moderate linear dependence emerged in the control group $(r$ squared $=0.83$, correlation $=0.62, p$ value 0.006$)$.

\section{Discussion}

The primary aim of this study was to investigate the diagnostic performance of SCD14-ST in postmortem serum from femoral blood in order to identify sepsis-related fatalities. The usefulness of sCD14-ST was compared to that of PCT which represents, at present, the laboratory parameter of choice in the realm of forensic investigations to corroborate the hypothesis of sepsis as the cause of death based on clinical, anamnestic, macroscopic, and microscopic findings. A cutoff value of $600 \mathrm{pg} / \mathrm{ml}$ was chosen based on the results of the clinical study of Endo et al. [4] in living people. We furthermore wished to test the usefulness of pericardial fluid as an alternative biological fluid for sCD14-ST determination.

Concerning the first objective of the study, the results of our analyses indicated that postmortem serum PCT and sCD14-ST levels, individually considered, allow septic cases to be identified.

Even though simultaneous increases in both PCT and sCD14-ST levels were observed in the control cases, most of the septic cases were characterized by concomitant increases in both markers, thus suggesting that their combined determination can be a useful tool in confirming the existence of septic states or sepsis-related fatalities.

Since sepsis is a major cause of mortality in intensive care units, reliable diagnoses may have a major impact on the clinical course, management, and outcome [7, 23] of these cases. In clinical situations, biochemical markers that could discriminate between non-infectious SIRS and sepsis as well as between infections of bacterial or viral etiology would be of great importance in making effective treatment decisions [23, 24].

In the realm of forensic pathology, autopsy findings and routine histology in cases of suspected fatal bacterial sepsis are most often unspecific and unconvincing. The identification of biochemical parameters that reliably add to the postmortem diagnosis of sepsis is highly desirable for medicolegal purposes [25-30].

CD14 is a GPI-anchored protein constitutively expressed by cells of myeloid origin. Aside from the membrane-bound state (mCD14), CD14 is also found in a circulating soluble form ( $\mathrm{sCD} 14$ ). $\mathrm{mCD} 14$ has been shown to be a specific receptor for lipopolysaccharide (LPS), a compound from the outer cell wall of Gram-negative bacteria. LPS circulating in blood is carried by the LPS-binding protein (LBP), an acute-phase protein, where the LPS-LBP complex may subsequently interact with the cell surface receptor mCD14 and form a high affinity trimolecular complex LBP-LPSCD14. This complex mediates monocyte activation via Tolllike receptors, thus inducing the release of a cascade of proinflammatory cytokines [31-36]. Besides binding LPS, CD14 may function as a receptor for peptidoglycan, the major cell wall component of Gram-positive bacteria [17, $18]$.

A soluble form of CD14, that lacks the GPI anchor, can be shed by activated monocytes from the plasma membrane and circulate in relatively high concentrations in normal, adult human serum, also binding bacterial structures [18, 34, 36]. Moreover, it can be suggested that sCD14 could be an acute-phase protein since, apart from a protease-mediated shedding form originating from leukocytes, a soluble form is also produced by hepatocytes, representing the major source of acute-phase proteins. However, though CD14 is known to be synthesized in human hepatocytes, nothing is known about the humoral mediators that regulate its production [18].

Evidence has accumulated to show that SCD14 serves as an acute-phase reactant parallel with CRP, a classical acutephase protein [36]. In a study of Bas et al. [18], sCD14 levels were elevated in various inflammatory arthropathies (infection-mediated, crystal-induced, and immunologically mediated) and correlated with those of CRP and IL-6.

Numerous clinical studies have reported significantly elevated serum levels of sCD14 in inflammatory conditions such as Kawasaki disease, atopic dermatitis, liver disease, rheumatoid arthritis, systemic lupus erythematosus, and primary Sjögren syndrome. Correlations between sCD14 levels and disease activity in systemic lupus erythematosus and the severity of trauma in polytraumatized patients have also been published [32, 37-45].

sCD14 plasma concentrations in adults and neonatal septic cases have been investigated in several studies and compared by some authors with other biochemical markers levels of inflammation and infection, mainly PCT, CRP, interleukin-6, tumor necrosis factor-alpha, LPS, and LBP [7, 23, 35, 36, 46-49]. The results of these studies showed increased sCD14 values in newborns and adults with sepsis as well as higher sCD14 levels in septic cases than in healthy control individuals. Pavcnik-Arnol et al. [23] observed that the diagnostic accuracy of sCD14 for sepsis was markedly higher in neonates than in children and superior to that of PCT, which suggested a distinct regulation of biochemical mediators for inflammation and infection in neonates and children. Berner et al. [35] observed significantly elevated sCD14 and LBP levels in samples from septic neonates when compared to samples from healthy control neonates. Furthermore, the authors documented elevated concentration of either SCD14 or LBP in 15 cases of infection caused by Gram-positive bacteria, which do not possess 
LPS as constituents of their cell wall. These findings suggested that, apart from Gram-negative bacteria, Grampositive bacteria are also capable of inducing significant sCD14 increases in vivo. Blanco et al. [48] documented increased sCD14 values in Gram-positive bacteria septic cases, though to a lesser extent than in Gram-negative bacteria sepsis. Herrmann et al. [7] and Landmann et al. $[46,47]$ observed higher sCD14 plasma concentrations in septic cases than in healthy control individuals, with the highest levels in patients with non-Gram-negative sepsis [47]. Again, these findings suggested that, apart from LPS of Gram-negative bacteria, sCD14 may also bind to cell wall components of Gram-positive microorganisms or mycobacteria and that bacterial wall components other than LPS may induce increases in $\mathrm{SCD} 14$ serum levels.

The truncated form of sCD14, renamed sCD14 subtype (sCD14-ST) or presepsin, is a novel marker for the diagnosis of sepsis that has been shown to increase in blood in the early stages of sepsis [50]. Yaegashi et al. [19] observed that the levels of sCD14-ST in septic patients were significantly higher than those in patients with SIRS or healthy control subjects. Compared with PCT, sCD14-ST was induced at earlier stages of sepsis, was present at higher concentrations in plasma and was a more sensitive indicator of sepsis.

In a multicenter prospective study performed by Endo et al. [4], the presepsin assay was as helpful for the diagnosis of bacterial infections as PCT, with no significant differences in presepsin levels between Gram-positive and Gramnegative bacterial infection groups. Despite a comparable usefulness of presepsin to PCT for the diagnosis of bacterial infections, the clinical specificity of sCD14-ST proved significantly higher than that of PCT, with several falsepositive PCT patients displaying SCD14-ST levels less than $600 \mathrm{pg} / \mathrm{ml}$. According to the authors, the presepsin cutoff value of $600 \mathrm{pg} / \mathrm{ml}$ yielded optimal sensitivity and specificity. Interestingly, sCD14-ST levels in two patients suffering from chronic renal failure were markedly increased, suggesting caution in interpreting presepsin levels above the cutoff value in such patients.

The results of our analyses seem to confirm the findings obtained by Yaegashi et al. [19] and Endo et al. [4], indicating that cases of bacterial sepsis are characterized by increased sCD14-ST levels in postmortem serum from femoral blood.

Indeed, only one individual (case 10, PCT 47.13) among sepsis-related fatalities presented a SCD14-ST value lower than $600 \mathrm{pg} / \mathrm{ml}$ along with a normal CRP concentration ( $3 \mathrm{mg} / \mathrm{l})$. This case was the only child of the studied septic group. It is interesting to notice that Maeda et al. [51] had already described normal postmortem serum CRP levels in some infantile pneumonia cases. The authors ascribed this result to an age-dependent limited inflammatory response.

However, Pavcnik-Arnol et al. [23] observed that the diagnostic accuracy of sCD14 for sepsis was higher in neonates than in children and superior to that of PCT which suggested, according to the authors, a distinct regulation of biochemical mediators for inflammation and infection in neonates and children. The results of Pavcnik-Arnol et al. [23] are based on clinical observations obtained in a larger, more representative septic population and partly contradict those of our analyses, which are based on a single infantile septic case.

Though further studies are required to confirm our findings, the results of our investigations indicated a high diagnostic accuracy for PCT and SCD14-ST in detecting sepsisrelated fatalities in the postmortem period. Coherent PCT and SCD14-ST results could thereby represent a promising diagnostic tool in forensic pathology to corroborate the existence of septic states.

We must highlight, however, the speculation that sCD14ST may partly continue to generate in the early postmortem period since circulating plasma proteases activate the cleavage of sCD14 to produce CD14-ST. Henceforth, a sCD14ST cutoff value greater than $600 \mathrm{pg} / \mathrm{ml}$ might be more realistic in forensic pathology.

According to this rationale, the results of data analysis showed that sensitivity and specificity were unmodified using a cutoff value of $750 \mathrm{pg} / \mathrm{ml}$, whereas specificity was significantly improved using a cutoff value of $1,200 \mathrm{pg} / \mathrm{ml}$.

Our results also revealed that SCD14-ST increases coherently with CRP levels in almost all cases. This observation can be extended to both septic and control individuals, with the only exceptions being cases 14 and 15 in the control group. These findings would corroborate the function of $\mathrm{CD} 14 / \mathrm{sCD} 14-\mathrm{ST}$ as an acute-phase reactant, as already postulated by numerous clinical studies.

Lastly, no associations were identified between postmortem serum and pericardial fluid sCD14-ST levels in either the septic or control groups. This means that sCD14-ST determination in pericardial fluid cannot be considered an alternative to postmortem serum when postmortem biochemistry could help in identifying the cause of death and postmortem serum is not available during autopsy.

In conclusion, the results of our investigations indicate that, as in the clinical field, sCD14-ST can be considered a promising biological parameter for the diagnosis of sepsis in forensic pathology routine.

Simultaneous assessments of PCT and SCD14-ST should be performed on a case-by-case basis when contradictory findings require further investigations, and measurements of other biochemical markers may be helpful in order to reach more definite conclusions.

Conflicts of interest The authors have no conflict of interest to declare. GEPA S.r.l. had no role in the study design, data collection, data analysis, data interpretation, or writing of the report. No financial support was received from GEPA S.r.l. for the preparation of this manuscript, the material used for the analyses, the laboratory equipment, or the laboratory personnel involved in this study. 


\section{References}

1. Gaïni A, Koldkjaer OG, Møller HJ, Pedersen C, Pedersen SS (2007) Comparison of high-mobility group-box 1 protein, lipopolysaccharide-binding protein and procalcitonin in severe community-acquired infections and bacteraemia: A prospective study. Crit Care 11(4):R76. doi:10.1186/cc5967

2. Schrag B, Iglesias K, Mangin P, Palmiere C (2012) Procalcitonin and C-reactive protein in pericardial fluid for postmortem diagnosis of sepsis. Int J Leg Med 126(4):567-72

3. Porcel JM, Vives M, Cao G, Bielsa S, Ruiz-González A, MartínezIribarren A, Esquerda A (2009) Biomarkers of infection for the differential diagnosis of pleural effusions. Eur Respir J 34 (6):1383-9

4. Endo S, Suzuki Y, Takahashi G, Shozushima T, Ishikura H, Murai A, Nishida T, Irie Y, Miura M, Iguchi H, Fukui Y, Tanaka K, Nojima T, Okamura Y (2012) Usefulness of presepsin in the diagnosis of sepsis in a multicenter prospective study. J Infect Chemother. doi:10.1007/s10156-012-0435-2

5. Palmiere C, Mangin P (2012) Postmortem chemistry update part II. Int J Leg Med 126(2):199-215

6. Schrag B, Roux-Lombard P, Schneiter D, Vaucher P, Mangin P, Palmiere C (2012) Evaluation of C-reactive protein, procalcitonin, tumor necrosis factor alpha, interleukin-6, and interleukin-8 as diagnostic parameters in sepsis-related fatalities. Int J Legal Med 126(4):505-12

7. Herrmann W, Ecker D, Quast S, Klieden M, Rose S, Marzi I (2000) Comparison of procalcitonin, sCD14 and interleukin-6 values in septic patients. Clin Chem Lab Med 38(1):41-6

8. Eberhard OK, Haubitz M, Brunkhorst FM, Kliem V, Koch KM, Brunkhorst R (1997) Usefulness of procalcitonin for differentiation between activity of systemic autoimmune disease (systemic lupus erythematosus/systemic antineutrophil cytoplasmic antibody-associated vasculitis) and invasive bacterial infection. Arthritis Rheum 40(7):1250-6

9. Lindahl B, Toss H, Siegbahn A, Venge P, Wallentin L (2000) Markers of myocardial damage and inflammation in relation to long-term mortality in unstable coronary artery disease. FRISC Study Group. Fragmin during instability in coronary artery disease. N Engl J Med 343(16):1139-47

10. Reinhart K, Meisner M, Brinkhorst FM (2006) Markers for sepsis diagnosis: What is useful? Crit Care Clin 22(6):503-19

11. Tong HS, Liu YS, Wen Q, Tang YQ, Yuan FF, Su L (2012) Serum procalcitonin predicting mortality in exertional heatstroke. Emerg Med J 29(2):113-7

12. Hausfater P, Hurtado M, Pease S, Juillien G, Lvovschi VE, Salehabadi S, Lidove O, Wollf M, Bernard M, Chollet-Martin S, Riou B (2008) Is procalcitonine a marker of critical illness in heatstroke? Intensive Care Med 34(8):1377-83

13. Nylén ES, Al Arifi A, Becker KL, Snider RH Jr, Alzeer A (1997) Effect of classic heatstroke on serum procalcitonin. Crit Care Med 25(8):1362-5

14. Balci C, Sivaci R, Akbulut G, Karabekir HS (2009) Procalcitonin levels as an early marker in patients with multiple trauma under intensive care. J Int Med Res 37(6):1709-17

15. Maier M, Wutzler S, Lehnert M, Szermutzky M, Wyen H, Bingold T, Henrich D, Walcher F, Marzi I (2009) Serum procalcitonin levels in patients with multiple injuries including visceral trauma. J Trauma 66(1):243-9

16. Mussap M, Degrandi R, Cataldi L, Fanos V, Plebani M (2007) Biochemical markers for the early assessment of neonatal sepsis: The role of procalcitonin. J Chemother 19(Suppl 2):35-8

17. Mussap M, Noto A, Fravega M, Fanos V (2011) Soluble CD14 subtype presepsin (sCD14-ST) and lipopolysaccharide binding protein (LBP) in neonatal sepsis: New clinical and analytical perspectives for two old biomarkers. J Matern Fetal Neonatal Med 24(Suppl 2):12-4

18. Bas S, Gauthier BR, Spenato U, Stingelin S, Gabay C (2004) CD14 is an acute-phase protein. J Immunol 172(7):4470-9

19. Yaegashi Y, Shirakawa K, Sato N, Suzuki Y, Kojika M, Imai S, Takahashi G, Miyata M, Furusako S, Endo S (2005) Evaluation of a newly identified soluble CD14 subtype as a marker for sepsis. J Infect Chemother 11(5):234-8

20. Obata K, Segawa O, Yakabe M, Ishida Y, Kuroita T, Ikeda K, Kawakami B, Kawamura Y, Yohda M, Matsunaga T, Tajima H (2001) Development of a novel method for operating magnetic particles, Magtration Technology, and its use for automating nucleic acid purification. J Biosci Bioeng 91(5):500-3

21. Okamura Y, Yokoi H (2011) Development of a point-of-care assay system for measurement of presepsin (sCD14-ST). Clin Chim Acta 412(23-24):2157-61

22. NCCLS. Protocols for determination of limits of detection and limits of quantitation; approved guideline. NCCLS document 2004 EP17-A [ISBN 1-56238-551-8]. Nccls, 940 West Valley Road, Suite 1400, Wayne, Pennsylvania 19087-1898 USA, 2004.

23. Pavnik-Arnol M, Hojker S, Derganc M (2007) Lypopolysaccharide-binding protein, lipopolysaccharide, and soluble CD14 in sepsis of critically ill neonates and children. Intensive Care Med 33(6):1025-32

24. Chalupa P, Beran O, Herwald H, Kaspř́ková N, Holub M (2011) Evaluation of potential biomarkers for the discrimination of bacterial and viral infections. Infection 39(5):411-7

25. Tsokos M (2007) Postmortem diagnosis of sepsis. Forensic Sci Int 165(2-3):155-64

26. Tsokos M, Reichelt U, Nierhaus A, Püschel K (2001) Serum procalcitonin (PCT): A valuable biochemical parameter for the postmortem diagnosis of sepsis. Int J Legal Med 114(4-5):237-43

27. Tsokos M, Reichelt U, Jung R, Nierhaus A, Püschel K (2001) Interleukin-6 and C-reactive protein serum levels in sepsis-related fatalities during the early postmortem period. Forensic Sci Int 119(1):47-56

28. Tsokos M, Fehlauer F, Püschel K (2000) Immunohistochemical expression of E-selectin in sepsis-induced lung injury. Int J Legal Med 113(6):338-42

29. Tsokos M, Fehlauer F (2001) Postmortem markers of sepsis: An immunohistochemical study using VLA-4 (CD49d/CD29) and ICAM-1 (CD54) for the detection of sepsis-induced lung injury. Int J Legal Med 114:291-94

30. Reichelt U, Jung R, Nierhaus A, Tsokos M (2005) Serial monitoring of interleukin- $1 \beta$, soluble interleukin- 2 receptor and lipopolysaccharide binding protein levels after death. A comparative evaluation of potential postmortem markers of sepsis. Int J Legal Med 119(2):80-87

31. Wright SD, Ramos RA, Tobias PS, Ulevitch RJ, Mathison JC (1990) CD14, a receptor for complexes of lipopolysaccharide (LPS) and LPS binding protein. Science 249(4975):1431-3

32. Krüger C, Schütt C, Obertacke U, Joka T, Müller FE, Knöller J, Köller M, König W, Schönfeld W (1991) Serum CD14 levels in polytraumatized and severely burned patients. Clin Exp Immunol 85(2):297-301

33. Jabara HH, Vercelli D (1994) Engagement of CD14 on monocytes inhibits the synthesis of human Igs, including IgE. J Immunol 153 (3): $972-8$

34. Bussolati B, David S, Cambi V, Tobias PS, Camussi G (2002) Urinary soluble CD14 mediates human proximal tubular epithelial cell injury induced by LPS. Int J Mol Med 10(4):441-9

35. Berner R, Fürll B, Stelter F, Dröse J, Müller HP, Schütt C (2002) Elevated levels of lipopolysaccharide-binding protein and soluble CD14 in plasma in neonatal early-onset sepsis. Clin Diagn Lab Immunol 9(2):440-5

36. Aalto H, Takala A, Kautiainen H, Siitonen S, Repo H (2007) Monocyte CD14 and soluble CD14 in predicting mortality of 
patients with severe community acquired infection. Scand J Infect Dis 39(6-7):596-603

37. Takeshita S, Nakatani K, Tsujimoto H, Kawamura Y, Kawase H, Sekine I (2000) Increased levels of circulating soluble CD14 in Kawasaki disease. Clin Exp Immunol 119(2):376-81

38. Wüthrich B, Kägi MK, Joller-Jemelka H (1992) Soluble CD14 but not interleukin-6 is a new marker for clinical activity in atopic dermatitis. Arch Dermatol Res 284(6):339-42

39. Oesterreicher C, Pfeffel F, Petermann D, Müller C (1995) Increased in vitro production and serum levels of the soluble lipopolysaccharide receptor sCD14 in liver disease. J Hepatol 23 (4):396-402

40. Horneff G, Sack U, Kalden JR, Emmrich F, Burmester GR (1993) Reduction of monocyte-macrophage activation markers upon antiCD4 treatment. Decreased levels of IL-1, IL-6, neopterin and soluble CD14 in patients with rheumatoid arthritis. Clin Exp Immunol 91(2):207-13

41. Yu S, Nakashima N, Xu BH, Matsuda T, Izumihara A, Sunahara N, Nakamura T, Tsukano M, Matsuyama T (1998) Pathological significance of elevated soluble CD14 production in rheumatoid arthritis: In the presence of soluble CD14, lipopolysaccharides at low concentrations activate RA synovial fibroblasts. Rheumatol Int 17(6):237-43

42. Egerer K, Feist E, Rohr U, Pruss A, Burmester GR, Dörner T (2000) Increased serum soluble CD14, ICAM-1 and E-selectin correlate with disease activity and prognosis in systemic lupus erythematosus. Lupus 9(8):614-21

43. Nockher WA, Wigand R, Schoeppe W, Scherberich JE (1994) Elevated levels of soluble CD14 in serum of patients with systemic lupus erythematosus. Clin Exp Immunol 96(1):15-9
44. Gebhard F, Rösch M, Helm M, Strecker W, Buttenschön K, Kinzl L, Bock KH, Brückner UB (1997) Is the activity of soluble CD14 enhanced following major trauma? Arch Surg 132(10):1116-20

45. Carrillo EH, Gordon L, Goode E, Davis E, Polk HC Jr (2001) Early elevation of soluble CD14 may help identify trauma patients at high risk for infection. J Trauma 50(5):810-6

46. Landmann R, Zimmerli W, Sansano S, Link S, Hahn A, Glauser MP, Calandra T (1995) Increased circulating soluble CD14 is associated with high mortality in gram-negative septic shock. J Infect Dis 171(3):639-44

47. Landmann R, Reber AM, Sansano S, Zimmerli W (1996) Function of soluble CD14 in serum from patients with septic shock. J Infect Dis 173(3):661-8

48. Blanco A, Solis G, Arranz E, Coto GD, Ramos A, Telleria J (1996) Serum levels of CD14 in neonatal sepsis by Gram-positive and Gram-negative bacteria. Acta Paediatr 85(6):728-32

49. Kitchens RL, Thompson PA (2003) Impact of sepsis-induced changes in plasma on LPS interactions with monocytes and plasma lipoproteins: Roles of soluble CD14, LBP, and acute phase lipoproteins. J Endotoxin Res 9(2):113-8

50. Shozushima T, Takahashi G, Matsumoto N, Kojika M, Okamura Y, Endo S (2011) Usefulness of presepsin (sCD14-ST) measurements as a marker for the diagnosis and severity of sepsis that satisfied diagnostic criteria of systemic inflammatory response syndrome. J Infect Chemother 17(6):764-9

51. Maeda H, Zhu BL, Bessho Y, Ishikawa T, Quan L, Michiue T, Zhao D, Li DR, Komatsu A (2008) Postmortem serum nitrogen compounds and $\mathrm{C}$-reactive protein levels with special regard to investigation of fatal hyperthermia. Forensic Sci Med Pathol 4 (3):175-80 